\title{
Does the Growth Acceleration Program Accelerate Growth?*
}

\author{
Julio Mereb** \\ Eduardo Zilberman ${ }^{* * *}$
}

\begin{abstract}
In this paper, we introduce the required time lag for the public investment to be turned into public capital (time-to-build process) in the neoclassical growth model, as well as distortionary tax rates that are adjusted according to the level of public debt. The purpose is to quantitatively isolate the macroeconomic effects of the increase in public investment observed in PAC (Portuguese acronym for Growth Acceleration Program). Depending on the time lag associated to the time-to-build process and the fiscal adjustment policy, PAC could have led to a GDP decrease between $0.2 \%$ and $0.4 \%$ in up to four years.
\end{abstract}

Keywords: Public Investment, Time-to-Build, Growth.

JEL Codes: H54, O41.

\footnotetext{
${ }^{*}$ Submitted in July 2013. Revised in September 2013. The authors would like to thank Tiago Couto Berriel, Braz Camargo, Carlos Viana de Carvalho and Rogério L. Furquim Werneck for the valuable comments and suggestions. Any remaining mistakes are entirely our responsibility.

${ }^{* *}$ Departamento de Economia, PUC-Rio, Brazil. E-mail: julio.mereb@gmail.com

*** Departamento de Economia, PUC-Rio, Brazil. E-mail: zilberman@econ.puc-rio.br
}

Brazilian Review of Econometrics

v. $32, \mathrm{n}^{\circ} 2$, pp. 133-167 November 2012 


\section{Introduction}

Many economists consider the public investment as an ideal countercyclical policy instrument. In the short run, more investments would boost the aggregate demand, and in the long run, would increase the public capital stock and, therefore, the overall productivity of the economy. ${ }^{1}$ This thesis is widely supported by the conventional growth models that include public capital in the production technology, such as the model described in Baxter and King (1993). However, Leeper et al. (2010), when considering the time lag needed for the government investment to be converted into public capital stock (time-to-build process), argue that an increase in government spending could slow down the economy in the short run.

In this work, the neoclassical growth model extended for public capital is used to quantitatively isolate the effect of the increase in public investment observed in the Growth Acceleration Program (in Portuguese, Programa de Aceleração do Crescimento - PAC), implemented by the Brazilian federal government between 2007 and 2010. In a calibration set for the Brazilian economy, the behavior of output, hours worked, private consumption and the private and public capital stock are analyzed in response to the exogenous increase in the public investment. ${ }^{2}$ In the theoretical approach, the time-to-build process in building the public capital is incorporated into the model, as well as distortionary tax rates which vary according to the accumulated public sector debt. ${ }^{3}$

Once included, these elements drastically reduce the expansionary effects of public investment, inducing a decrease in GDP of $0.2 \%$ up to $0.4 \%$ in a period of four years. The magnitude of the recession depends on how the government investment is financed (through taxes on consumption, labor or capital), as well as the intensity of the time-to-build process. Moreover, aggressive fiscal adjustments, reducing the public debt in up to 5 years, could have a significant role in the GDP growth in the short run. In the case of a more flexible fiscal stance, which corrects the government debt trajectory in up to 15 years, the GDP could be affected for over 10 years.

The recessionary impact of the public investment shock stems from an expectation of a larger stock of infrastructure in the future, when the current government investment will be effectively developed into public capital. The higher is the level of public capital in the future, the higher is the marginal productivity (that is, income) of the inputs used in the private sector. This expectation of higher in-

\footnotetext{
${ }^{1}$ We understand public capital to be infrastructure provided by the public sector, for example, ports, railroads, roads, hydroelectric plants, etc.

${ }^{2}$ This paper does not intend to model every feature of the PAC, but to concentrate on the short and long run quantitative effects of the increase in public investment in Brazil.

${ }^{3}$ Other recent papers use the neoclassical framework extended for public capital to quantitatively analyze the impact of different fiscal policies in Brazil. For instance: Ferreira and Nascimento (2006), Pereira and Ferreira (2010) and Santana et al. (2012). The main contribution of this paper to the existing literature is to include the time-to-build process in building the public capital.
} 
come in the future creates a positive income effect that reduces the labor supply, as well as intertemporal substitution effects on labor and private investment. Consequently, both variables decrease in response to the shock, until the new public capital is available for production. ${ }^{4}$ This short run recessionary effect is present even if the public investment is funded without distortions (with lump-sum taxes). However, if distortive taxes are used to finance the investment, the recessionary impact increases.

In the long run, when the building of public capital is concluded, the increase in the marginal productivity of the inputs favors private capital accumulation and the increase in hours worked, elevating the level of aggregate output.

Finally, the theoretical mechanism through which the public investment induces a short run recession has been validated recently in a purely empirical exercise. In fact, Leduc and Wilson (2012) estimated the impulse response functions of employment and GDP to non-anticipated shocks on public investment in roads in the United Sates. The authors report that this kind of expenditure causes a short run recession. After the downturn, which lasts up to four years after the shock, there is an increase in the level of activity. However, the results suggest no long run effects, ten years after the initial shock.

\section{The Growth Acceleration Program}

\subsection{Description}

In January 2007, the Federal Government released the Growth Acceleration Program (PAC for the Portuguese acronym), implementing several economic stimulus packages and institutional reforms, in order to increase the GDP growth rate. ${ }^{5}$ Basically, the PAC tried to revive the role of the Federal Government as a planner of economic development by eliminating economic bottlenecks through infrastructure projects. The first phase of the program lasted four years, from 2007 to 2010 , and, in 2011, the Federal Government launched the PAC 2, with very similar goals. In short, there are three large groups of measures implemented between 2007 and 2010 .

First, the government attempted to reduce taxes on housing investments and infrastructure projects, as well as the acquisition of machinery and equipment. An important measure was the introduction of the PEC 233/2008, which plans to unify some federal consumption taxes in the so-called IVA-F as well as to reduce

\footnotetext{
${ }^{4}$ Notice that the negative income effect associated to the current increase in public expenditure - which, as documented in Barro (1981), stimulates the labor supply and the GDP can be reversed by the impact that future increments in the public capital stock play in the contemporary decisions of the agents.

${ }^{5}$ The description of the PAC is based on reports published periodically by the Finance Ministry, in which economic measures, information and data pertaining to the program are divulged, as well as newspaper articles from Folha de São Paulo, O Estado de São Paulo and O Globo. See bibliographic references.
} 
ICMS [a state value-added tax on services and circulation of goods] and simplify its tax law. Other measures proposed by the PEC 233/2008 include the reduction of taxes on payroll and essential goods. However, the tax bill is still waiting for enactment by the Congress.

Second, the government sought to increase real estate credit for individuals, especially with the program "Minha Casa, Minha Vida" (My Home, My Life). The PAC also sought to finance working capital for infrastructure and logistic projects implemented by private companies. In fact, BNDES [a Brazilian national development bank] has received over $R \$ 100$ billion in 2010 from the Federal Government to finance private companies. Other measures include the creation of the Infrastructure Investment Fund, financed with FGTS [a public pension fund] resources, and the increase in the credit limit for the Public Sector, in order to invest in sanitation and housing.

Finally, the third PAC measure was the increase in government and state owned companies investments in large infrastructure projects, especially in energy and transportation. Out of the $\mathrm{R} \$ 402.1$ billion allotted (not including the $\mathrm{R} \$ 216.9$ billion from PAC earmarked for loans to individuals) between 2007 and 2010, R\$ 274.1 billion were investments implemented by the government and state-owned companies in infrastructure. The purpose of this paper is to isolate and evaluate the macroeconomic impacts of the increase in government investment (not including state owned companies) associated to the PAC.

Considering the mega projects started in the first PAC, three can be highlighted as remarkable examples: the construction of the Transnortheastern railway, the North-South railway and the transfer of the San Francisco river. The first two had already been started by previous governments, but had not been finished. The Federal Government then decided to resume and increase their scope in the PAC. Although the projects are very ambitious, all of them are unfinished and sustain substantial implementation delays. In fact, the government intended to finish the Transnortheastern railway $(1,728 \mathrm{~km})$ in the end of 2010 , but, in that same year, it had already postponed its inauguration to 2012. ${ }^{6}$ In the São Francisco river transfer, in May 2012, only 36\% had been completed. These examples give us the real dimension of the time-to-build process associated with the public investment, which is crucial to quantify the macroeconomic effects of PAC.

\subsection{PAC, Time-to-Build Process and the Public Investment}

The PAC is an example of how the time-to-build process can be relevant. The program increased the public investment rate from $1.8 \%$ of GDP (average for the $2002-2006$ period) to $2.3 \%$ (average for the $2007-2010$ period). However, the average of the amount invested in proportion to the GDP for the last period was of over $2.5 \%$, which corresponds to an increase of nearly $10 \%$ of the investment

\footnotetext{
${ }^{6}$ Conclusion date was pushed again to 2015. In May 2013, less than half of the project had been completed.
} 
rate between 2007 and $2010 .^{7}$ The difference in magnitude between these two measures reflects the restrictions the government faces - from the institutional aspect of the intricate Brazilian legislation to the actual building of the projects, which demands a large amount of resources.

In Table 1 there is a brief description of the PAC execution. The first line shows the annual public investment rate. The second shows the rate of public investment restricted to expenses with constructions related to PAC. ${ }^{8}$ The third calculates the difference between these two variables and therefore, shows the public investment rate minus the expenditure with the program. In turn, the fourth line shows the amount spent in projects related to PAC in proportion to the GDP. The fifth line shows the sum of the third and fourth lines, thus displaying the public investment rate that corresponds to the amounts spent by the government in PAC projects. Finally, the sixth line shows the ratio between the public investment rate observed in the data and the public investment rate approved.

Table 1

Public Investment Rate Discriminated by PAC Expenditure

\begin{tabular}{lcccc}
\hline & 2007 & 2008 & 2009 & 2010 \\
\hline (1) Public Investment (\%) & 1.8 & 2.2 & 2.3 & 2.8 \\
(2) PAC Invesment (\%) & 0.3 & 0.4 & 0.5 & 0.5 \\
(3) Expenditures Excluding PAC (\%) & 1.5 & 1.9 & 1.8 & 2.3 \\
(4) Amount Spent: PAC Projects (\%) & 0.6 & 0.6 & 0.7 & 0.7 \\
(5) Approved investment rate (\%) & 2.1 & 2.5 & 2.5 & 2.9 \\
(6) Ratio: Line (5)/Line (1) & 1.19 & 1.11 & 1.08 & 1.05 \\
\hline
\end{tabular}

Variables correspond to proportions of GDP in each year.

Source: IPEA and SOF.

Hence, the sixth line offers an imperfect measurement of the discrepancy between approved public expenditure and public investment, to the extent that, from 2008 on, one cannot associate the amount earmarked in a particular year to the amount spent in that same year, and, thus, distinguish it from the funds earmarked in the years before. Therefore, the decrease in the ratio during the four-year period could have been caused by the spending of earmarked funds accrued in previous years, and not by a greater promptness in implementing the projects throughout the period.

In any case, in 2007, the authorized public investment rate is nearly $20 \%$ larger

${ }^{7}$ Public investment is measured according to three phases of execution, as formally described in the fiscal accounts: approval, liquidation and payment. The approval occurs when the funds are earmarked for the project. Then, after the delivery of goods or conclusion of the service, there is the liquidation, when the infrastructure project is legally included as an asset in the public sector balance sheet. Finally, in the phase of payment, the government meets the obligations incurred by the contract with the firm responsible for the execution of the project.

${ }^{8}$ The data pertaining to the amount paid for projects were used to calculate PAC investments. 
than that observed in the data. These differences reflect the inherent difficulties associated to the execution of large infrastructure projects. Table 2 shows the participation of PAC expenditure in the public investment rate observed in the data. The average participation of PAC investments in the public investment rate is of nearly $20 \%$.

Table 2

Participation of PAC in the Public Investment Rate

\begin{tabular}{lcccc}
\hline & 2007 & 2008 & 2009 & 2010 \\
\hline PAC Invesments (\%) & 15 & 17 & 22 & 19 \\
Expenditures Excluding PAC (\%) & 85 & 83 & 78 & 81 \\
\hline Source: IPEA and SOF. & & & &
\end{tabular}

\section{Model}

\subsection{Households}

Assume a closed economy with a representative household that derives utility from private consumption $(c)$, government consumption $\left(g^{c}\right)$ and leisure $(l)$. The instantaneous utility is given by:

$$
U\left(c_{t}, g_{t}^{c}, l_{t}\right)=\frac{\left[\left(c_{t}+\theta g_{t}^{c}\right)^{\chi} l_{t}^{1-\chi}\right]^{1-\sigma}}{1-\sigma}
$$

where $\chi$ measures the utility of consumption relative to leisure, and $\theta \in[0,1]$ is a parameter that measures the gains from government consumption. The specification for the relation between private and public consumption follows, among others, Barro (1981). The inverse of the intertemporal elasticity of substitution is $\sigma$. Given the format of the instantaneous utility and the discount factor $\in(0,1)$, the family orders different consumption and leisure paths $\left\{c_{t}, g_{t}^{c}, l_{t}\right\}_{t=0}^{\infty}$ through

$$
\sum_{t=0}^{\infty} \beta^{t} U\left(c_{t}, g_{t}^{c}, l_{t}\right)
$$

For each period, the representative household is faced with a budget constraint given by

$$
\begin{aligned}
\left(1+\tau_{t}^{c}\right) c_{t}+k_{t+1} & +b_{t+1} \\
& \leq\left(1-\tau_{t}^{h}\right) w_{t} h_{t}+\left[\left(1-\tau_{t}^{k}\right) r_{t}^{k}+1-\delta\right] k_{t}+\left(1+r_{t}\right) b_{t}(2)
\end{aligned}
$$

where $w$ represents the wages, and $h$ the total of worked hours. The time endowment is normalized to one, so that $h=1-l$. The household has access to a market 
of government bonds, which for that period pay an interest rate $r . b$ is the stock of public bonds held by the family, $r^{k}$ represents the interest rate on private capital and $\delta$ is the depreciation rate. $\tau_{t}^{c}$,

$\operatorname{tau} u_{t}^{h}, \tau_{t}^{k}$ are marginal tax rates on consumption, labor income and interests from capital.

Given $\left\{w_{t}, r_{t}, g_{t}^{c}, \tau_{t}^{c}, \tau_{t}^{h}, \tau_{t}^{k}\right\}, k_{0}$ and $b_{0}$, the problem of the representative household is to choose trajectories $\left\{c_{t}, h_{t}, l_{t}, b_{t+1}, k_{t+1}\right\}$ that maximize (1) subject to the budget constraint (2) and $h_{t}=1-l_{t}$, for every $t$.

From the first order conditions of the household problem, the labor supply decision is such that:

$$
\left(\frac{1-\chi}{\chi}\right)\left[\frac{\left(c_{t}+\theta g_{t}^{c}\right)}{1-h_{t}}\right]=\frac{w_{t}\left(1-\tau_{t}^{n}\right)}{1+\tau_{t}^{c}}
$$

and we can obtain the Euler equations given by

$$
\frac{1}{1+\tau_{t}^{c}} U_{c}\left(c_{t}, g_{t}^{c}, l_{t}\right)=\frac{\beta}{1+\tau_{t+1}^{c}} U_{c}\left(c_{t+1}, g_{t+1}^{c}, l_{t+1}\right)\left[\left(1-\tau_{t}^{k}\right) r_{t+1}^{k}+1-\delta\right]
$$

and

$$
\frac{1}{1+\tau_{t}^{c}} U_{c}\left(c_{t}, g_{t}^{c}, l_{t}\right)=\frac{\beta}{1+\tau_{t+1}^{c}} U_{c}\left(c_{t+1}, g_{t+1}^{c}, l_{t+1}\right)\left(1+r_{t+1}\right)
$$

which induce a no-arbitrage condition in the economy.

\subsection{Production}

Production is carried out by a representative firm. At each period, this firm produces a good $(y)$ using capital $(k)$, labor $(h)$ and public capital $\left(K^{g}\right)$ through the following technology:

$$
y_{t}=k_{t}^{\alpha} h_{t}^{1-\alpha}\left(K_{t}^{g}\right)^{\gamma}
$$

The specification on public capital follows, among others, Barro (1990). Although the production function has constant scale returns in relation to private inputs, the public capital is included to generate a positive externality over the production process, with intensity measured by $\gamma>0$.

The first order conditions for the competitive firm problem implies that, for all periods,

$$
r_{t}^{k}=\alpha \frac{y_{t}}{k_{t}} ; w_{t}=(1-\alpha) \frac{y_{t}}{h_{t}}
$$




\subsection{Government}

Each period the government collects taxes on capital interests, consumption and wages for worked hours, and also finances itself through the issuing of bonds for that period. The budget restriction for the government, for each period, is given by:

$$
g_{t}^{c}+g_{t}^{i}+r_{t} b_{t}=g_{t}+b_{t+1}-b_{t}
$$

where $g_{t}=\tau_{t}^{c} c_{t}+\tau_{t}^{h} w_{t} h_{t}+\tau_{t}^{k} r_{t}^{k} k_{t}$ is the government revenue from taxes and $g_{t}^{i}$ is the public investment.

The marginal tax rates $\tau_{t}^{c}, \tau_{t}^{h}, \tau_{t}^{k}$ can be adjusted each period, according to the government debt to GDP ratio, $s_{t}=b_{t} / y_{t}$ :

$$
\tau_{t}^{j}=\tau^{j} \exp \left\{\varphi_{j}\left(s_{t}-s\right)\right\}, j=c, h, k
$$

where $\tau^{j}$ and $s$ are, respectively, a tax rate and the debt to GDP ratio in the steady-state. The parameter $\varphi_{j}$ is the semi-elasticity of the marginal tax rate in relation to the deviation of $s_{t}$ from $s$. Higher $\varphi_{j}$ values indicate a more aggressive fiscal adjustment policy. Notice that $s$ can be interpreted as the long term debt to GDP ratio which the government is committed to achieving.

\subsubsection{Time-to-Build Process Modeling}

In this paper, as in Leeper et al. (2010), the government investment is materialized into public capital through the time-to-build process, which reflects the period of time between granting budget authorization and completing a project. ${ }^{9}$ This specification for the flow of public investment differs from the usual one, in which the authorized spending is immediately implemented, and therefore, incorporated in the public capital stock on the next period.

Considering that $N$ is the number of periods between granting the budget and completing the project, we can specify the evolution of public capital stock as:

$$
K_{t}^{g}=\left(1-\delta_{g}\right) K_{t-1}^{g}+g_{t-N}^{a}
$$

where $g^{a}$ represents the government expenditure approved in the budget or the public investment stock. The time-to-build process is defined by the equation (3), since a given project whose financing was authorized in $t-N$ can only be incorporated in the productive public capital stock of $t$ in the period $t-1$.

However, the expenditures approved in the budget are carried out progressively during the project execution period, according to the expenditure rate $\phi_{0}, \phi_{1}, \phi_{2}, \ldots, \phi_{N-1}$. The government investment flow is defined in $t$ as:

\footnotetext{
${ }^{9}$ The funds earmarked for public investment in the data corresponds, in the model, to the authorized spending in the government budget.
} 


$$
g_{t}^{i}=\sum_{n=0}^{N-1} \phi_{n} g_{t-n}^{a}
$$

with $\sum_{n=0}^{N-1} \phi_{n}=1$.

\subsubsection{Fiscal Rules}

We assume that the government follows fiscal rules, so that the approved public investment and government consumption are determined, respectively, as exogenous proportions $\pi_{0}$ and $\pi_{1}$ of the aggregate output. That is:

$$
g_{t}^{a}=\pi_{0} y_{t} \quad \text { and } \quad g_{t}^{c}=\pi_{1} y_{t}
$$

\subsection{Market Clearing Conditions}

The model is closed with the market clearing condition in the goods market:

$$
c_{t}+k_{t+1}-(1-\delta) k_{t}+g_{t}^{c}+g_{t}^{i}=y_{t}
$$

Finally, the equilibrium concept considered is the competitive one, with its standard definition.

\section{Calibration}

The calibration of parameters is set to match key Brazilian economic data from 2000 to 2006, adjusting the relevant variables for a three-month period.

\subsection{Tax Rates}

The calibration of tax rates on consumption, wages for worked hours and interests earned by capital is based on tax revenue data of the Federal, State and City Governments. ${ }^{10}$ Revenues are discriminated by each tax group from 2000 to 2006.

The marginal tax rate on consumption, $\tau^{c}$, was calculated by the ratio between tax revenue on households' consumption and aggregate consumption in National Accounts, yielding $\tau^{c}=0.23$, the average for the period from 2000 to 2006. The taxes levied on households' consumption are basically IPI [a federal excise tax on the manufacturing of goods], ICMS [a state value-added tax on services and circulation of goods], taxes on imports, ISS [taxes on services] and COFINS [Social Security Financing Contribution].

Due to the difficulties in measuring data related to earnings from capital and the wage bill in Brazil, we use the lowest tax rates levied on capital and worked hours calculated in the period, so that the calibration gets closer to the recent

\footnotetext{
${ }^{10}$ Data from IBGE (Brazilian Institute of Geography and Statistics).
} 
empirical literature, as Paes and Bugarin (2006). ${ }^{11}$ Thus, the tax rate on capital was calibrated to $\tau^{k}=0.14$, obtained by the ratio between the tax revenues (IRPJ [corporations income tax], IRRF [income tax withheld] on capital, CSLL [federal tax levied on corporations for the financing of social security], IPTU [municipal property tax], IPVA [motor vehicle property tax] and CPMF [Provisional Contribution on Financial Transfers]) and profits in the National Accounts.

Finally, the tax rate on wages was obtained by the ratio between tax revenues and the payroll (employees' wages plus gross income in the informal sector), yielding $\tau^{h}=0.22$. The tax revenue on paychecks includes taxes that correspond to IRPF [individual income tax], social security contribution, FGTS [Employee Severance Indemnity Guarantee Fund], PIS/PASEP [Social Integration Program/ Public Servant Fund] and labor IRRF [income tax withheld].

\subsection{Technology and Preferences Parameters}

We turn to the calibration of the technology parameters. Using the annual data for public and private capital stock, the quarterly depreciation rates found are $\delta=0.014$ and $\delta_{g}=0.009$ (equivalent to annual depreciation rates of $5.5 \%$ and $3.5 \%$, respectively).

There is no consensus in the literature regarding the value associated with the parameter $\gamma$, which captures the importance of public capital in the production function. A pioneer attempt is found in Aschauer (1989), which estimates it at 0.24. However, alternative estimations, such as in Lynde and Richmond (1993) and Holtz-Eakin (1994), are inconclusive. In Brazil, Ferreira and Maliagros (1998) found the elasticity of long term GDP to infrastructure to be above 0.4. Due to the lack of consensus over the appropriate value for $\gamma$, a conservative calibration $(\gamma=0.10)$ was adopted following Baxter and King (1993) and Leeper et al. (2010). For a sensibility analysis, a very high value is set for $\gamma(\gamma=0.35)$, reflecting possible bottlenecks that may affect some productive sectors of the Brazilian economy.

We turn to the calibration of the preferences parameters. The steady-state real interest rate for government bonds is set at $6 \%$ a year (which is the same as a quarterly interest rate of $r=0.015)$. In the steady-state, using the Euler equation, we found $\beta=\frac{1}{1+r}=0.986$. Given this value, we found $r^{k}=0.0327$ for a quarterly interest rate on capital (equivalent to an annual rate of $13.4 \%$ ). The value $\alpha=0.40$ was obtained through the average of the private capital to GDP ratio between 2000 and 2006, $K / Y=3.1$, and the interest rate on the stock of private capital, $r^{k}$. Finally, $\chi$ was set so ensure that the households spends one fourth of the time endowment in labor services in steady-state $(h=0.25)$. This amount is consistent with the empirical evidence for Brazil, such as in Paes and

\footnotetext{
${ }^{11}$ The average rates, from 2000 to 2006 , for capital and worked hours are $\tau^{k}=0.18$ and $\tau^{h}=0.23$. The methodology used in this paper for the tax rates calibration is different from the one used in other papers, in which the model is calibrated for a specific year, and the tax rates are obtained given a value for $\alpha$ (for example, Pereira and Ferreira, 2010).
} 
Bugarin (2006) and Gonzaga et al. (2003).

The empirical literature in Brazil is rather scarce in regards to the parameter of intertemporal elasticity of substitution, $1 / \sigma$. In this case $\sigma=3$, a usual value in the literature, was used. ${ }^{12}$ Finally, the weight of the government consumption in the consumer's utility, $\theta$, was calibrated at $\theta=0.5$. Two extreme cases, $\theta=0$ and $\theta=1$, were also analyzed. ${ }^{13}$ In the first, the government consumption is a waste of resources and in the second one the private and the government consumption are perfect substitutes.

\subsection{Fiscal Policies and Time-to-Build Process Parameters}

We turn to the calibration of the fiscal policy parameters. First, we set $s=$ 2.04 , which is the average of the public sector net debt between 2000 and $2006 .{ }^{14}$ Afterwards, the values for $\pi_{0}$ and $\pi_{1}$ were calculated. Through the quarterly public investment data, $\pi_{1}=0.018$ was obtained. Given the Brazilian tax burden of $32 \%$, the average for the period, $\pi_{0}=g / y-\pi_{1}-r s=0.266$. Since $\pi_{0}$ is a residual parameter, this value is larger than the actual average participation of public administration consumption in the GDP, around $20 \%$.

For the sake of simplicity, we assume that the expenditure rate sequence $\left\{\phi_{n}\right\}_{n=0}^{N-1}$ is such that $\phi_{0}=0$ and $\phi_{n}=1 /(N-1)$ for every $n=1, \ldots, N-1$. We consider time lags of one quarter $\left(N=1\right.$ and $\left.\phi_{0}=1\right)$, two years $\left(N=8, \phi_{0}=0\right.$ and $\phi_{n}=1 / 7$ for $\left.n=1, \ldots, 7\right)$, three years $\left(N=12, \phi_{0}=0\right.$ and $\phi_{n}=1 / 11$ for $n=1, \ldots, 11)$ and four years $\left(N=16, \phi_{0}=0\right.$ and $\phi_{n}=1 / 15$ for $\left.n=1, \ldots, 15\right)$. Therefore, we suppose that the government does not spend any part of the earmarked resources for a given project in the period in which it is approved, and, after that, it spends evenly the authorized investment throughout time. A similar procedure is carried out by Kydland and Precott (1982) and Leeper et al. (2010). As we argue below, the best fit to the public investment data is obtained with a time lag of three years. In this case the government spends less than $10 \%$ of the earmarked amount in each quarter.

Table 3 summarizes the calibrated parameters. ${ }^{15}$

\footnotetext{
${ }^{12}$ Issler and Piqueira (2000) estimated a value of $\sigma=4$ for Brazil. The authors, however, took a cautious approach on interpreting the results.

${ }^{13}$ For $\theta=0$ and $\theta=1$, the adjustment $\chi=0.33$ and $\chi=0.41$, respectively, must be made to guarantee $h=0.25$.

${ }^{14}$ The value of $s=2.04$ correspond to the government debt stock in relation to the quarter GDP.

${ }^{15}$ Similar to Leeper et al. (2010), who incorporate the same time-to-build process in a neoclassical growth model, the parameters restrictions that guarantee the existence of a stable steadystate are not discussed. However, the numerical solution implemented suggests that, for the parameterization described in Table 3, a stable steady-state exists.
} 
Table 3

Model Calibrated Parameters

\begin{tabular}{|c|c|c|c|c|c|c|}
\hline \multicolumn{7}{|c|}{ Calibrated Parameters } \\
\hline \multicolumn{2}{|c|}{ Preferences } & \multicolumn{2}{|c|}{ Technology } & \multicolumn{3}{|c|}{ Government } \\
\hline$\beta$ & 0.986 & $\alpha$ & 0.40 & $\tau^{c}$ & 0.23 & $\pi_{0} 0.018$ \\
\hline$\chi$ & $0.38 / 0.33 / 0.4$ & $\gamma$ & 0.10 & $\tau^{h}$ & 0.22 & $\pi_{1} 0.266$ \\
\hline$\sigma$ & 3 & $\gamma$ & 0.014 & $\tau^{k}$ & 0.14 & \\
\hline$\theta$ & $0.5 / 0 / 1$ & $\delta_{g}$ & 0.009 & & & \\
\hline
\end{tabular}

\subsection{Fiscal Adjustment Scenarios}

Finally, the parameters $\varphi_{j}, j=c, h, k$ were calibrated, considering three alternative schemes of financing the increase in public investment. In each scheme, only one of the three tax rates $\tau^{c}, \tau^{h}, \tau^{k}$ can vary over time in order to guarantee the stability of the government debt to GDP ratio.

For each fiscal adjustment regime, the parameter $\varphi_{j}$ associated to the rate $\tau^{j}$ is calibrated for three different scenarios. In the first one, $\varphi_{j}$ is chosen so that the deviation from the debt to GDP ratio, $s_{t}$, from its steady state value, $s$, is lower than $5 \%$ in only 5 years. In the second, the procedure is analogous; however the goal for the deviation will be achieved in ten years. And, finally, in the last scenario, the goal will be reached in an even longer time frame, fifteen years. Hence, we simulate how the flexibilization of a given form of fiscal adjustment can affect the macroeconomic variables in the short and long run.

\subsection{Political Experiment: Simulating PAC}

The numerical simulation of the effects of PAC is done in three steps. First, the steady-state of the model, according to the parameters described in Table 3, is computed. Second, an unanticipated temporary shock on the authorized public investment, which changes from $\pi_{1}=0.018$ to $\pi_{1}=0.026$ for four years, returning to $\pi_{1}=0,018$ afterwards, is simulated in the model. Tables 1 and 2 corroborate the hypothesis that this shock represents the dynamics of the PAC authorized public investment. Finally, the equilibrium path is computed via the shooting algorithm method $^{16}$ incorporating one of the fiscal adjustment rules described above.

The simulations in the next section represent the quarterly impulse-response functions associated to the policy shock described above, for the cases in which the time lag is of two, three and four years. We also report simulations in which the time lag is of only one quarter (usual hypothesis in the macroeconomic models).

In the simulations, the time-to-build process corresponding to three years shows best fit to the quarterly and annual data. ${ }^{17}$ In Tables 4 and 5, the public invest-

\footnotetext{
${ }^{16}$ The shooting algorithm is described in Ljungqvist and Sargent (2012, Chapter 11).

${ }^{17}$ The choice of the time-to-build process was based on a simple criteria, in which the chosen time lag minimizes $\sum_{t=1}^{4}\left(i g_{t}^{\text {annual }}-\widehat{i g}_{t}^{\text {annual }}\right)^{2}+\sum_{t=1}^{16}\left(i g_{t}^{\text {quarterly }}-\widehat{i g}_{t}^{\text {quarterly }}\right)^{2}$, where $i g_{t}$ 
ment rates generated by the three-year time-to-build process and the one observed in the data are compared. ${ }^{18}$ The good fit of the model to the annual data, in Table 4, despite its simplicity, is noteworthy. Even if high frequency data are considered (quarterly), in Table 5, the suiting of the model is still reasonable. ${ }^{19}$

Table 4

Annual Public Investment Rate $(I g / Y)$ - Model and Data

\begin{tabular}{cccc}
\hline & Model & Data & Ratio \\
& $N=12(3$ years $)$ & $I g / Y$ annual & \\
\hline 2007 & 0.019 & 0.018 & 1.04 \\
2008 & 0.021 & 0.022 & 0.95 \\
2009 & 0.024 & 0.023 & 1.04 \\
2010 & 0.026 & 0.028 & 0.94 \\
\hline
\end{tabular}

Source: IPEA.

Considering the substantial delay of the PAC projects, the two-year time lag seems conservative and it is plausible to consider a four-year lag for the time-tobuild process. In this last case, the government spends a little bit more than $6 \%$ of the earmarked funds each quarter.

\section{Long Term and Short Term PAC Impacts}

In this section, we present and discuss the quarterly impulse response functions to an unanticipated shock to the rate of public investment, which increases to $\pi_{1}=0.026$ for four years and returns to $\pi_{1}=0.018$ afterwards.

\subsection{Benchmark: Lump-Sum Tax Financing}

Before the analysis of the distortionary fiscal adjustment schemes (via consumption, labor and capital taxes), we show that, even in the case of a lump-sum tax framework, the public investment shock may have a recessionary impact on output. ${ }^{20}$ Figure 1 shows the impulse response functions.

and $\widehat{i g}_{t}$ represent the public investment rate observed in the data and the model, respectively.

${ }^{18}$ The public investment rate reported in the tables corresponds to the model in which the tax rates remain constant in time, and the government adjusts the budget through lump-sum taxes. See subsection 5.1.

${ }^{19}$ In the Appendix, the investment rates generated by the time lag of two and four years are reported. In the first case, the model tends to overestimate the public investment rate, both in the annual and quarterly frequencies. In the second case, the opposite happens; there is an underestimation of the data. However, the adjustment is still better with a time lag associated with four years.

${ }^{20}$ Within a lump-sum tax financing scheme, the Ricardian equivalence is valid and, thus, the specific path of taxes is not important to determine the equilibrium, but only its present value. See Ljungqvist and Sargent (2012, Chapter 10). 
Table 5

Quarterly Public Investment Rate $(I g / Y)$ - Model and Data

\begin{tabular}{lccc}
\hline & Model & Data & Ratio \\
& $N=12(3$ years $)$ & $I g / Y$ quarterly & \\
\hline $2007 / 1 \mathrm{Q}$ & 0.018 & 0.018 & 0.99 \\
$2007 / 2 \mathrm{Q}$ & 0.018 & 0.018 & 1.00 \\
$2007 / 3 \mathrm{Q}$ & 0.019 & 0.017 & 1.08 \\
$2007 / 4 \mathrm{Q}$ & 0.019 & 0.017 & 1.14 \\
$2008 / 1 \mathrm{Q}$ & 0.020 & 0.019 & 1.04 \\
$2008 / 2 \mathrm{Q}$ & 0.021 & 0.021 & 1.01 \\
$2008 / 3 \mathrm{Q}$ & 0.022 & 0.023 & 0.92 \\
$2008 / 4 \mathrm{Q}$ & 0.022 & 0.025 & 0.89 \\
$2009 / 1 \mathrm{Q}$ & 0.023 & 0.021 & 1.12 \\
$2009 / 2 \mathrm{Q}$ & 0.024 & 0.023 & 1.04 \\
$2009 / 3 \mathrm{Q}$ & 0.025 & 0.023 & 1.05 \\
$2009 / 4 \mathrm{Q}$ & 0.025 & 0.024 & 1.04 \\
$2010 / 1 \mathrm{Q}$ & 0.026 & 0.025 & 1.03 \\
$2010 / 2 \mathrm{Q}$ & 0.026 & 0.028 & 0.91 \\
$2010 / 3 \mathrm{Q}$ & 0.026 & 0.029 & 0.89 \\
$2010 / 4 \mathrm{Q}$ & 0.026 & 0.027 & 0.97 \\
\hline
\end{tabular}

Public investment data is seasonally adjusted.

Source: IPEA.

Figure 1

Response to the public investment shock: Lump-sum tax financing
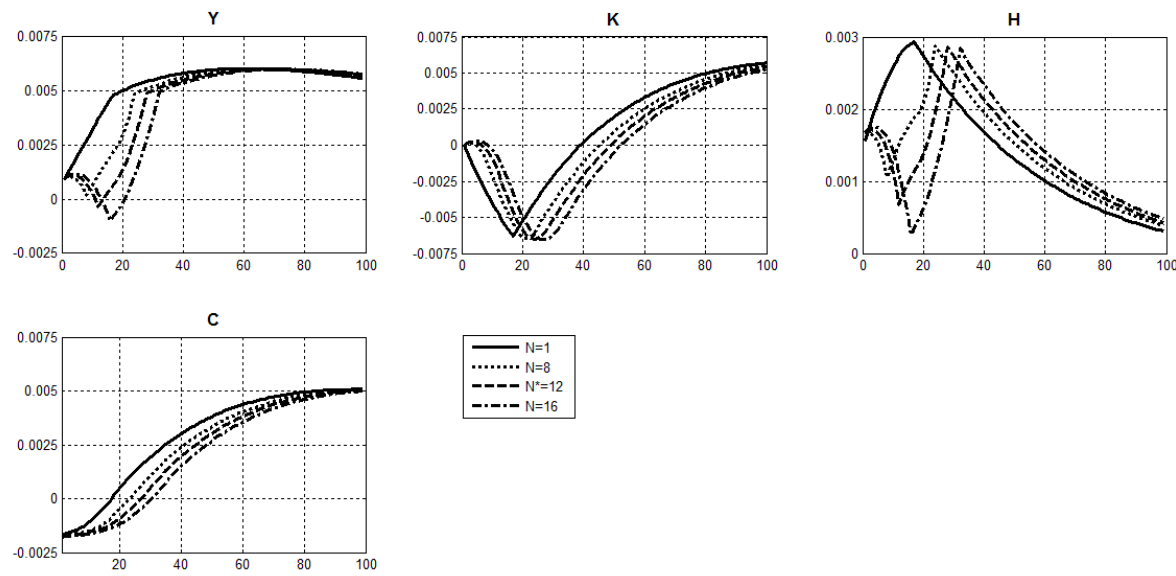
Note that the PAC can be recessionary in the short run, depending on the intensity of the time-to-build process, so that the GDP can be below its stationary level at a specific time frame for the time-to-build process.

In the exercise, this happens when the implementation delays on the public investment are larger than three years.

The economic mechanism behind the result is due to the time-to-build process in the formation of public capital, which operates as a sort of technological constraint, restricting the rapid consolidation of the infrastructure in the economy. In fact, the agents, anticipating that the increase of public investment will be translated into a higher public capital stock in the future, decide at the same time to reduce the hours worked and postpone investment decisions. These economic decisions are caused by the increase in future marginal product of inputs (that is, income), which creates a positive income effect on the labor supply and intertemporal substitution effects on both labor and private investment. In the short run, both income and substitution effects, in response to an increase in public investment, attenuate the increase in hours worked and the decrease in the private capital stock.

Although it is very unlikely that the resources designated for PAC can be mobilized without allocative distortions, this exercise shows that the time-to-build process alone is enough for the public investment to be recessionary in the short run. In the following sections, quantitative exercises allowing for distortionary taxation - and, thus, more adequate to reality - show that the recessionary trait of PAC can be significantly amplified.

\subsection{Distortionary Tax Financing}

Figures 2, 3 and 4 show the quarterly impulse response functions to a public investment shock. The simulations show the dynamics of variables for four implementation time lags of public expenditures: one quarter (solid line); eight quarters (dotted line); 12 quarters (dashed line); and 16 quarters (dashed-dotted line). The three-year time lag is the baseline case, since it shows the best fit to both quarterly and annual data. The reported simulations consider the case in which the debt to GDP ratio deviation to its value in steady state is lower than $5 \%$ in fifteen years. This scenario was chosen to allow PAC to have a greater expansionary effect in the short run, since the fiscal adjustment scheme is less aggressive. Thus, the graphs show the most favorable scenario for PAC.

Even with a greater fiscal flexibility, the increase in public investment expenditures is associated with a recessionary effect on the GDP in the short run, for any time lag greater than one quarter. For the three-year time lag, the decrease in the variable is of around $0.2 \%$, and may reach $0.3 \%$ if the time-to-build process takes four years. Moreover, the long run expansionary effect of PAC is modest in all the three cases shown, and the peak in the growth path can be reached in a very long period. For instance, when taxes are levied on consumption, the GDP 
Figure 2

Response to the public investment shock: Consumption taxation $\left(\tau_{c}\right)$
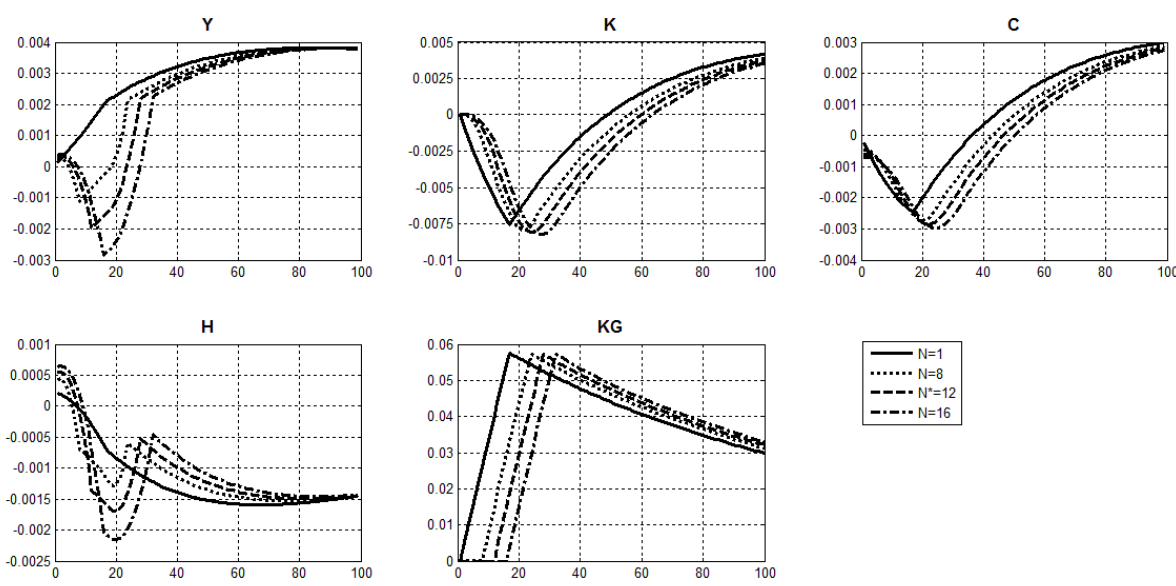

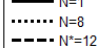 \\ \begin{tabular}{ll}
$-\cdots N=16$ \\
\hdashline$-\cdots N=12$
\end{tabular}}

Figure 3

Response to public investment shock: Labor taxation $\left(\tau_{h}\right)$
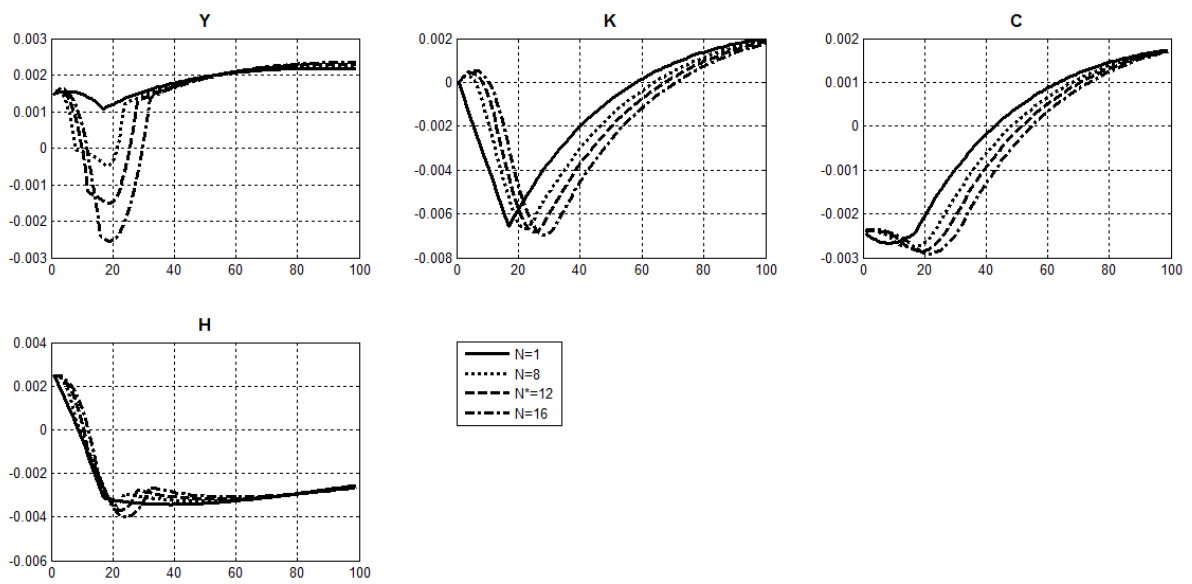

\section{$\underset{\mathrm{N}}{\mathrm{N}=1}+\mathrm{N}_{\mathrm{N}}$}

$\ddot{---\mathrm{N}^{*}=12}$ 
Figure 4

Response to public investment shock: Capital taxation $\left(\tau_{k}\right)$
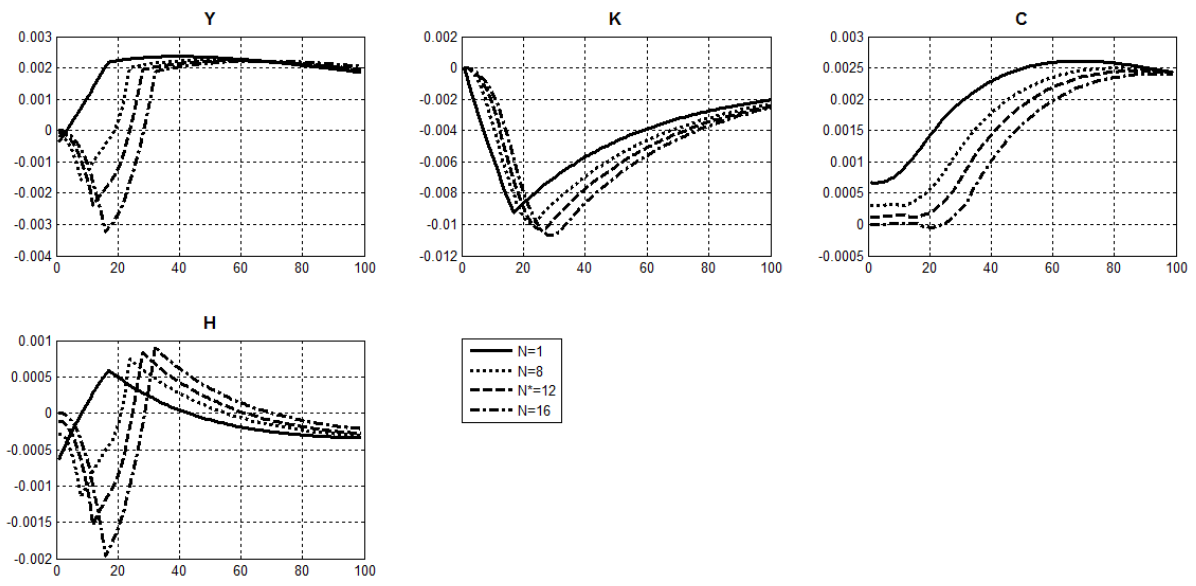

reaches its growth peak of $0.4 \%$ in twenty years, and this can be reduced to little over $0.2 \%$ in alternative financing schemes. However, despite being modest, the impact of the public investment on the GDP is long lived, because of the lower value associated with the depreciation of public capital in Brazil. In this manner, the transition dynamics of variables are very long, spanning over fifty years.

In Figure 2, the $K^{g}$ graph shows the growth path of the public capital stock. The impulse response function is reported only for the case in which the consumption taxes finance the government spending, since the public capital path is identical in other fiscal adjustment schemes. In the graph, it can be noted how distinct time-to-build processes can induce very different dynamics in the short run, even if the quantitative increase in the public capital stock, of nearly $6 \%$, is the same for alternative implementation lags. When the public investment is immediately implemented, the public capital growth path reaches its peak in four years. However, even for a smaller time lag (two years), the growth peak is reached two years after the previous case. For even larger time lags, the peak can be delayed for seven or eight years. Therefore, the impact on the productive capacity of the economy, given by the increase in the public capital stock, is progressively delayed as the lags in government investment increases.

Turning to the private capital stock, the decrease in the short run is attenuated in all the three figures as the public investment takes longer time to be implemented. In the medium run, however, the effect is reversed, and the fall in private capital is deeper. In fact, if the fiscal adjustment is based on capital taxes, the decline in the capital stock can overshoot 1\%, which does not happen for lower lags in government expenditures. Considering the long run path, the fis- 
cal adjustment based on consumption taxes induces a larger capital accumulation, and the stock rises nearly $0.5 \%$ in 25 years. However, for this same time frame, when the adjustment happens with a higher taxation on capital, the capital stock remains $0.2 \%$ lower than the steady-state level. This comparison underscores how alternative financing schemes can induce very distinct long run dynamics.

The consumption, on the other hand, shows similar dynamics across the alternative implementation lags, except when the fiscal adjustment is performed through capital taxes. In this case, the increase in taxes induces the agent to dissave throughout the equilibrium path. As a consequence, consumption remains above the stationary level in the transition dynamics, and reaches a growth peak of little over $0.25 \%$. Moreover, similarly to what happens to other variables, the long run growth is larger when consumption taxes finance government expenses (over $0.3 \%$ ). If the fiscal adjustment is based on taxation of hours worked, the growth peak is reduced to $0.2 \%$.

Finally, the initial increase in hours worked is rapidly reverted when taxes are levied on consumption or labor. ${ }^{21}$ The effect is due to the decrease in real wages the agent actually receives in both cases. In fact, the decrease in hours worked can reach $0.4 \%$ with implementation lags of four years and higher labor taxation. Considering capital taxation, a prompt reduction in hours worked occurs in the short run (between $0.1 \%$ and $0.2 \%$ ), and the decline increases directly with the lags in government spending.

Later, there is a slight increase in worked hours of less than $0.1 \%$. Notice that, in all the three cases, the time-to-build process attenuates the short run dynamics of the worked hours. This result, together with the attenuation of the decrease in consumption, is due to the positive income effect caused by the increase in public capital stock, in response to the expectation of a higher supply of goods in the future. ${ }^{22}$

\subsection{Flexibility of the Fiscal Adjustment}

This section analyzes how the distinct fiscal stances regarding the fiscal adjustments affect the behavior of macroeconomic variables in the short and long run. In Figures 5, 6 and 7, below, the impulse response functions associated to the public investment shock are shown. The underlying implementation delays of

\footnotetext{
${ }^{21}$ Ramey (2011) points out that, different from lump-sum taxation, models allowing for distorionary taxation tend to create, in the neoclassical growth model, a recessive effect on worked hours and output.

${ }^{22}$ Although the focus of this paper is to evaluate PAC on its main purpose, that is, to stimulate growth, it is worth mentioning that the gains in welfare associated with the program are modest. Welfare gains are measured as the percentage variation in consumption needed to render the representative agent indifferent between the economies with and without PAC. When $N=12$, for example, the welfare gains associated with the dynamics presented in Figures 2, 3 and 4 vary between $0.17 \%$ and $0.21 \%$, depending on how taxation is carried out. If lump-sum taxation is considered the welfare gains increase to 0.27
} 
government investment are of three years. However, for each form of government expenditure financing scheme, the semi-elasticities, $\varphi_{c}, \varphi_{h}$ and $\varphi_{k}$, vary according to the flexibility of fiscal adjustments, reflected in the number of periods chosen to stabilize the government debt: five (solid line), ten (dotted line) and fifteen years (dashed line), are imposed. In the graphs legend, the different values associated to the parameters $\varphi_{j}, j=c, h, k$ are shown.

Figure 5

Response to the public investment shock: Consumption taxation $\left(\tau_{c}\right)$
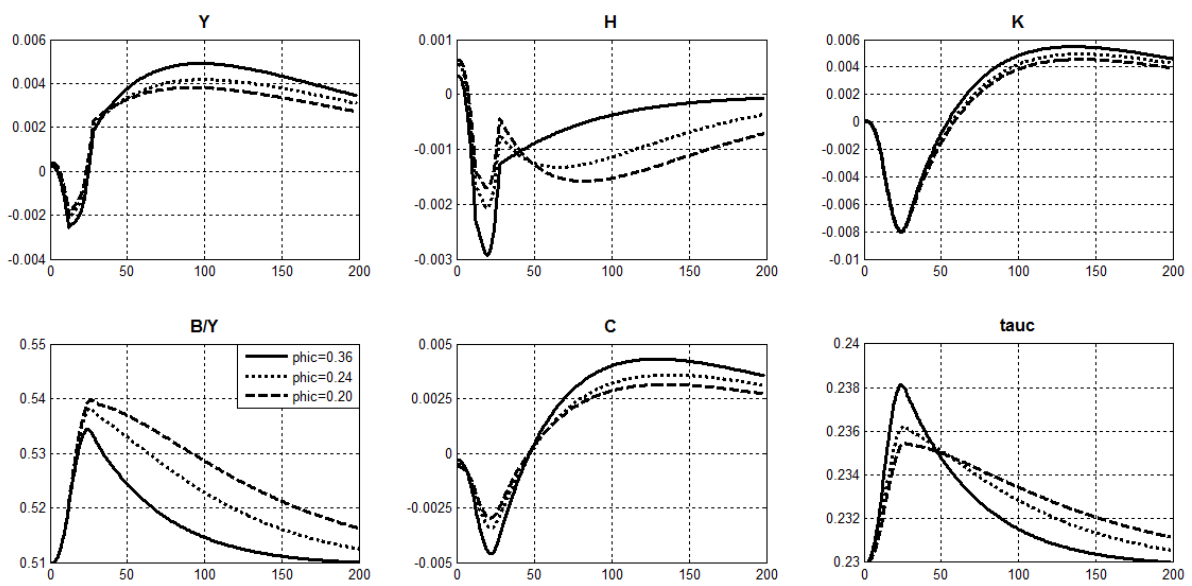

The effect of a more aggressive fiscal adjustment is not very important in the short run, except when the taxes are levied on worked hours. In fact, in the most aggressive scenario (five years), the fall in GDP can reach approximately $0.4 \%$ in five years, twice as much as the decrease associated to the ten-year scenario. In the other forms of financing, the short run effect is very similar for different stances regarding the fiscal policy. In fact, when the public debt is financed by taxes on consumption or capital, the decrease in the GDP is, respectively, around $0.2 \%$ and $0.3 \%$ across alternative scenarios. However, for each financing scheme, the less aggressive adjustments generate a lower GDP growth path in the long run.

The lower growth is due to the persistence of economic distortions induced by the higher tax rates. When the government loosens the debt dynamics in the long run, it becomes necessary to keep higher tax rates for a longer period of time, in order to guarantee the sustainability of the debt to GDP ratio. In effect, in the three financing schemes, the gap between the GDP trajectories across alternative scenarios lies between $0.1 \%$ and $0.2 \%$ for over ten years. Again, if the expenditures are covered by taxes on hours worked, the GDP growth rate in the five-year scenario can reach almost double of the rate achieved in the fifteen-year scenario. 
Figure 6

Response to the public investment shock: Labor taxation $\left(\tau_{h}\right)$
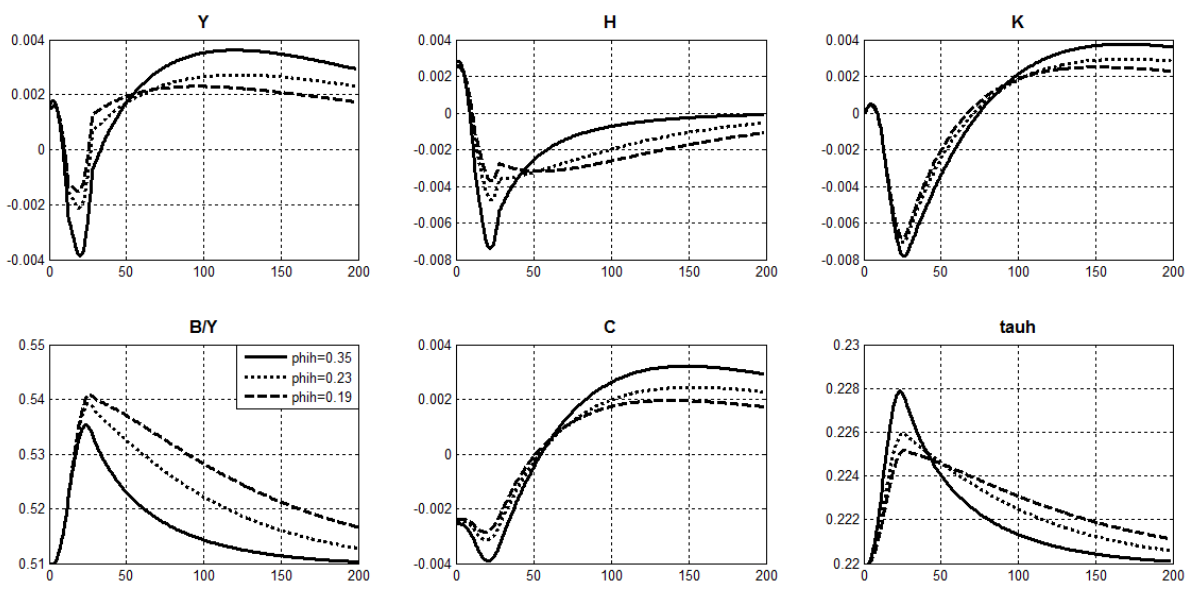

Figure 7

Response to the public investment shock: Capital taxation $\left(\tau_{k}\right)$
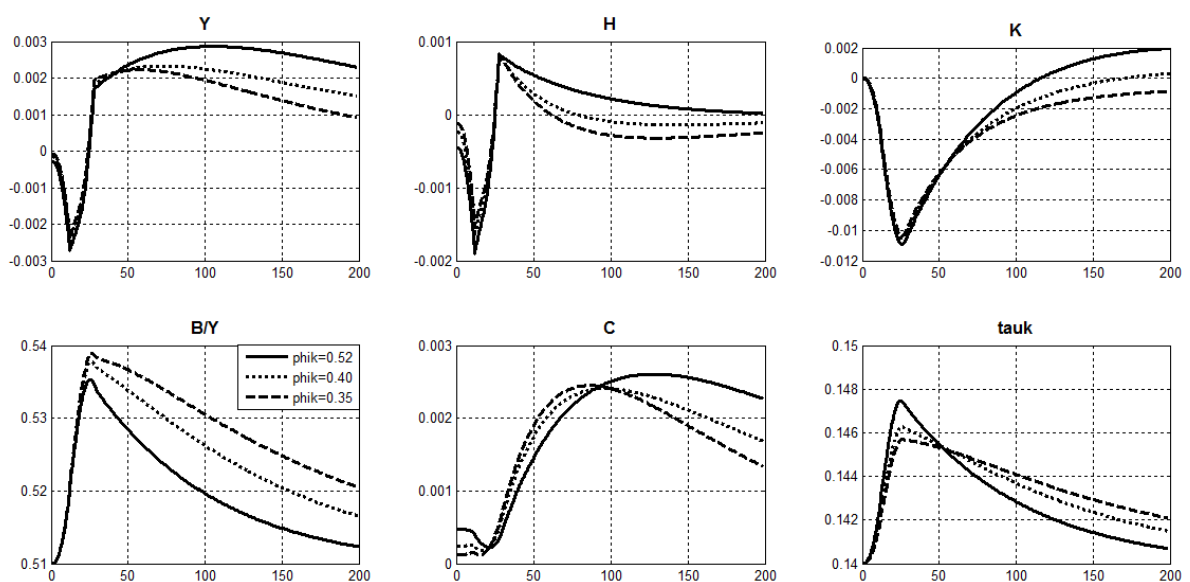
Also, given that the implementation lags for the government expenditures are high, of three years, PAC is recessionary in the short run in all the simulations.

In relation to the capital stock path, the variable does not exhibit significant disparities between the different fiscal stances in the short run. However, in the medium and long run, the more aggressive fiscal adjustment induces a larger private capital accumulation. In fact, when the expenditures are financed through capital taxes, the long run discrepancies are significant. In the less aggressive stance, the capital stock remains $0.15 \%$ lower than the stationary level, even twenty years after the initial shock. On the other hand, if the debt path is constrained in just five years, the same variable shows growth of over $0.2 \%$ in the long run. Notice that the extension of distortions can lead to greatly distinct trajectories for the variables.

With respect to the paths of consumption and hours worked, the quantitative differences in the short run are more relevant. In fact, when the government finances its expenditures through consumption taxes, the decrease in the variable reaches nearly $0.5 \%$ in the five-year scenario, whereas in the fifteen-year scenario, the decrease is slightly higher than $0.25 \%$. Similarly, when the higher taxes are levied on hours worked, the decrease in this variable in the short run is between $0.4 \%$ and $0.7 \%$ across alternative scenarios.

Thus, for the adopted calibration, the trade-off between the less and more aggressive fiscal stances tends to favor the more aggressive, except when public expenditures are financed through taxes on hours worked. Although more aggressive fiscal adjustments can cause significant distortions in the short run, they can also induce a higher growth trajectory in the medium and long run, when the government no longer needs to impose a hard tax burden on households. This effect becomes evident when comparing the tax rate paths across the alternative fiscal adjustment scenarios, for each form of taxation. The less aggressive is the adjustment, the lower is the tax rate peak, as well as the longer is the return to the stationary level. As a consequence, the debt to GDP ratio reaches higher levels, both in the short and long run.

\section{Sensitivity Analysis}

\subsection{Public Capital Productivity}

In the proposed calibration, the elasticity of GDP to public capital, $\gamma$, is low. However, some sectors constrained by economic bottlenecks suggest a higher level for $\gamma$, even though this is a technological parameter. This argument can be rationalized in a model including several complementary types of public capital (roads, ports, hydroelectric plants, among others). In this environment, wherever a specific type of capital is scarce, the productivity gains for investing in that capital can be much higher.

One of the few attempts to estimate the productivity of the public capital stock 
in Brazil was carried out by Ferreira and Maliagros (1998), who found values for the long term elasticity of GDP to infrastructure to be above 0.4. Hence, we consider an alternative calibration, in which $\gamma=0.35$. Figure 8 shows the impulse response functions for the same public investment shock analyzed before. The simulations consider implementation delays of three years, as well as a flexible fiscal adjustment, carried out in fifteen years. The impulse response function is reported for the three alternative taxation schemes (on consumption, labor and capital).

Notice that the decrease in GDP is close to $1 \%$ in four years. The result indicates that the recessionary impact of the public investment is amplified when $\gamma$ increases. Intuitively, the greater is the future productivity of the public capital, the greater is the expectation of higher earnings for the inputs in the future. Consequently, the positive income effect on the labor supply is amplified as well as the intertemporal substitution effects on labor and private investment. Moreover, the crowding-out effect on consumption, caused by the increase of public expenditures, is replaced by a growth trajectory during the transition to the new steady state.

Figure 8

Response to the public investment shock: $\gamma=0,35$
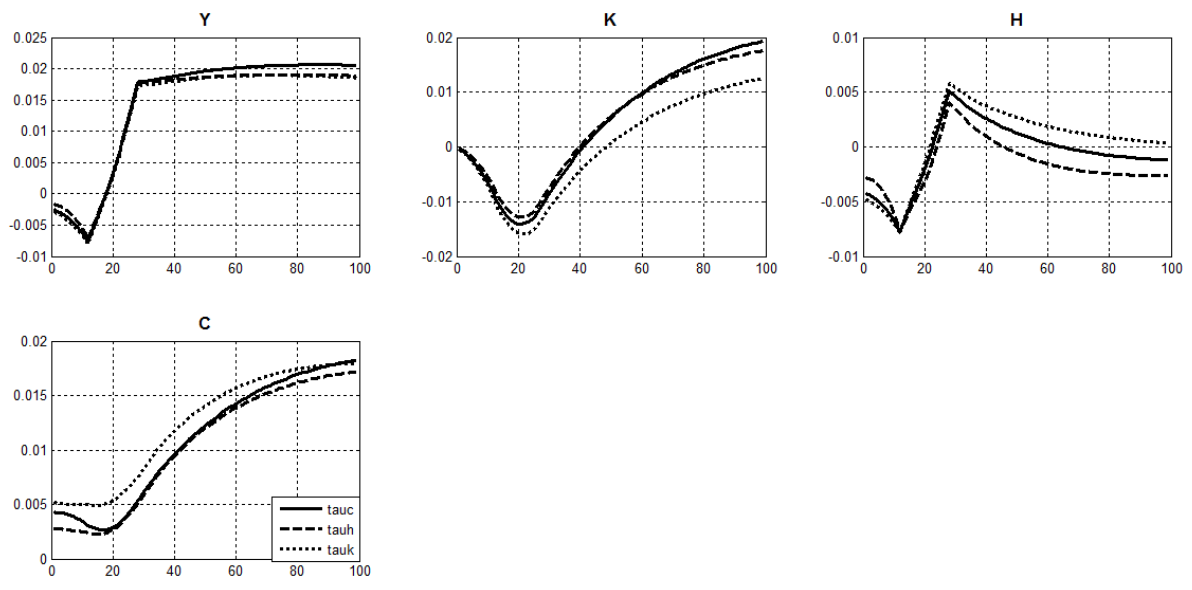

Finally, notice that the medium and long run expansionary effects are remarkable, reaching a GDP growth rate of around $2 \%$. Also, notice that the taxation on capital leads to a lower accumulation over the transition dynamics. Similarly, higher taxes on hours worked reduces the growth of labor supply. 


\subsection{Government Consumption in the Household Utility}

The Appendix reports the impulse response functions for alternative calibrations for the weight of government consumption in the household utility: $\theta=0$ (government consumption is complete waste) and $\theta=1$ (government consumption and private consumption are perfect substitutes). The qualitative results associated with the time-to-build process and with the distinct fiscal stances do not change, and quantitatively, the change in GDP growth rate is negligible.

The most relevant impacts are found in the impulse response functions for private consumption and hours worked in the short run, because different government consumption weights in the representative agent utility lead to distinct income-effects. According to Barro (1981), in response to an increase in public expenditures when $\theta=0$, the increase in hours worked tends to be larger as well as the decrease in consumption tends to be lower in comparison to the case of $\theta>0$. These results are due to a negative income effect on the agent, which is amplified when government expenditures do not generate positive externalities. In fact, these effects can be observed in the cases of higher taxation on consumption and hours worked. On the other hand, if government spending is financed through capital taxes, the growth of consumption over the transition dynamics is lower when $\theta=0$.

\section{Conclusion}

This paper uses the neoclassical growth model to isolate the public investment shock induced by the enactment of the PAC (Portuguese acronym for Growth Acceleration Program) in Brazil. The model incorporates government investment implementation delays for building public capital (time-to-build process) and distortionary tax rates, which are adjusted endogenously according to the size of the public debt. In a calibration for the Brazilian economy, the results show that the PAC induces a GDP decrease between $0.2 \%$ and $0.4 \%$ in three years, if the infrastructure takes the same three years to be available for use. The intensity of the recession varies according to the government financing scheme, as well as to the fiscal stance in response to an increase in public debt. When a larger public capital productivity is considered, the decrease in the GDP in the short run is amplified, reaching nearly $1 \%$.

Therefore, the model suggests that the efficacy of PAC as a countercyclical policy is highly questionable. The results suggest the slow implementation of projects associated to the PAC can induce a considerable downturn in the activity level, especially in sectors constrained by relevant economic bottlenecks. Moreover, the results also suggest that institutional improvements allowing for a prompter conclusion of infrastructure projects are crucial to promote productivity gains in a shorter time frame, and, thus, to mitigate its recessionary effect. 


\section{References}

Aschauer, D. (1989). Is public expenditure productive? American Economic Review, 75:117-127.

Barro, R. J. (1981). Output effects of government purchases. Journal of Political Economy, 89:1086-1121.

Barro, R. J. (1990). Government spending in a simple model of endogenous growth. Journal of Political Economy, 98:103-26.

Baxter, M. \& King, R. G. (1993). Fiscal policy in general equilibrium. American Economic Review, 83:315-334.

Ferreira, P. C. \& Maliagros, T. (1998). Impactos produtivos da infra-estrutura no Brasil - 1950/95. Pesquisa e Planejamento Econômico, 28:315-338.

Ferreira, P. C. \& Nascimento, L. G. (2006). Welfare and growth effects of alternative fiscal rules for infrastructure investment in Brazil. Ensaios Econômicos 604, FGV/EPGE.

Folha de São Paulo (2012). Transposição do Rio São Francisco está 36\% concluída, diz ministro. São Paulo, May 22.

Gonzaga, G., Machado, A. F., \& Machado, D. (2003). Horas de trabalho: Efeitos idade, período e corte. Texto para Discussão 473, PUC-Rio.

Holtz-Eakin, D. (1994). Public sector capital and productivity puzzle. Review of Economic and Statistics, 1:12-21.

Issler, P. \& Piqueira, N. S. (2000). Estimating relative risk a version, the discount rate, and the intertemporal elasticity of substitution in consumption for Brazil using three types of utility function. Brazilian Review of Econometrics, 20:201239.

Kydland, F. \& Precott, E. C. (1982). Time-to-build and aggregate fluctuations. Econometrica, 50:1345-1370.

Leduc, S. \& Wilson, D. (2012). Roads to prosperity or bridges to nowhere? Theory and evidence on the impact of public infrastructure investment. Working Paper 18042, NBER.

Leeper, M. E., Walker, B. T., \& Yang, S. S. (2010). Government investment and fiscal stimulus. Journal of Monetary Economics, 57:1000-1012.

Ljungqvist, L. \& Sargent, T. J. (2012). Recursive Macroeconomic Theory. The MIT Press, Massachusetts, third edition. 
Lynde, C. \& Richmond, J. (1993). Public capital and total factor productivity. International Economic Review, 34:401-414.

Ministério da Fazenda (2008). Balanço um ano, janeiro de 2008: PAC - Programa de Aceleração do Crescimento. Brasília.

Ministério da Fazenda (2009). Balanço dois anos, fevereiro de 2009: PAC - Programa de Aceleração do Crescimento. Brasília.

Ministério da Fazenda (2010a). Balanço quatro anos (2007-2010): PAC - Programa de Aceleração do Crescimento. Brasília.

Ministério da Fazenda (2010b). Balanço três anos, fevereiro de 2010: PAC Programa de Aceleração do Crescimento. Brasília.

O Estado de São Paulo (2013). Obra da Transnordestina nem chegou à metade, mas orçamento quase dobrou. São Paulo, May 25.

O Globo (2010). Norte-Sul é obra de cinco presidentes, enquanto Transnordestina não tem um quilômetro sequer entregue desde 2003. Rio de Janeiro, October 26 .

Paes, N. L. \& Bugarin, M. N. S. (2006). Parâmetros tributários da economia brasileira. Estudos Econômicos, 36:699-720.

Pereira, R. C. \& Ferreira, P. C. (2010). Avaliação dos impactos macroeconômicos e de bem-estar da reforma tributária no Brasil. Revista Brasileira de Economia, 64:191-208.

Ramey, V. A. (2011). Can government purchases stimulate the economy? Journal of Economic Literature, 49:673-85.

Santana, P. J., Cavalcanti, T. V. V., \& Paes, N. L. (2012). Impactos de longo prazo de reformas fiscais sobre a economia brasileira. Revista Brasileira de Economia, $66: 247-269$. 
A. Appendix

\section{A.1 Public Investment Rates: Data and Predictions in the Model}

\section{A.1.1 2-year Time-to-Build $(N=8)$}

Table A1: Public Investment Rate $(I g / Y)$ Annual - Model and Data

\begin{tabular}{cccc}
\hline & $\begin{array}{c}\text { Model } \\
N=8(2 \text { years })\end{array}$ & $\begin{array}{c}\text { Annual data } \\
I g / Y\end{array}$ & Ratio \\
\hline 2007 & 0.019 & 0.018 & 1.05 \\
2008 & 0.023 & 0.022 & 1.03 \\
2009 & 0.026 & 0.023 & 1.11 \\
2010 & 0.026 & 0.028 & 0.93 \\
\hline
\end{tabular}

Table A2: Public Investment Rate $(I g / Y)$ Quarterly - Model and Data

\begin{tabular}{cccc}
\hline & $\begin{array}{c}\text { Model } \\
\text { (2 years })\end{array}$ & $\begin{array}{c}\text { Quarterly data } \\
I g / Y\end{array}$ & Ratio \\
\hline $2007 / 1 \mathrm{Q}$ & 0.018 & 0.018 & 0.99 \\
$2007 / 2 \mathrm{Q}$ & 0.018 & 0.018 & 1.00 \\
$2007 / 3 \mathrm{Q}$ & 0.019 & 0.017 & 1.11 \\
$2007 / 4 \mathrm{Q}$ & 0.020 & 0.017 & 1.19 \\
$2008 / 1 \mathrm{Q}$ & 0.021 & 0.019 & 1.10 \\
$2008 / 2 \mathrm{Q}$ & 0.023 & 0.021 & 1.09 \\
$2008 / 3 \mathrm{Q}$ & 0.024 & 0.023 & 1.01 \\
$2008 / 4 \mathrm{Q}$ & 0.025 & 0.025 & 0.99 \\
$2009 / 1 \mathrm{Q}$ & 0.026 & 0.021 & 1.26 \\
$2009 / 2 \mathrm{Q}$ & 0.026 & 0.023 & 1.14 \\
$2009 / 3 \mathrm{Q}$ & 0.026 & 0.023 & 1.11 \\
$2009 / 4 \mathrm{Q}$ & 0.026 & 0.024 & 1.07 \\
$2010 / 1 \mathrm{Q}$ & 0.026 & 0.025 & 1.03 \\
$2010 / 2 \mathrm{Q}$ & 0.026 & 0.028 & 0.91 \\
$2010 / 3 \mathrm{Q}$ & 0.026 & 0.029 & 0.89 \\
$2010 / 4 \mathrm{Q}$ & 0.026 & 0.027 & 0.97 \\
\hline Pubic & &
\end{tabular}

Public investment data is seasonally adjusted.

Source: IPEA. 


\section{A.1.2 4-year Time-to-Build $(N=16)$}

Table A3: Public Investment Rate $(I g / Y)$ Annual - Model and Data

\begin{tabular}{cccc}
\hline & $\begin{array}{c}\text { Model } \\
N=16(4 \text { years })\end{array}$ & $\begin{array}{c}\text { Annual data } \\
I g / Y\end{array}$ & Ratio \\
\hline 2007 & 0.018 & 0.018 & 1.03 \\
2008 & 0.020 & 0.022 & 0.91 \\
2009 & 0.023 & 0.023 & 0.96 \\
2010 & 0.025 & 0.028 & 0.89 \\
\hline
\end{tabular}

Source: IPEA.

Table A4: Public Investment Rate $(I g / Y)$ Quarterly - Model and Data

\begin{tabular}{lccc}
\hline & $\begin{array}{c}\text { Model } \\
N=16(4 \text { years })\end{array}$ & $\begin{array}{c}\text { Quarterly data } \\
I g / Y\end{array}$ & Ratio \\
\hline $2007 / \mathrm{Q} 1$ & 0.018 & 0.018 & 0.99 \\
$2007 / \mathrm{Q} 2$ & 0.018 & 0.018 & 1.00 \\
$2007 / \mathrm{Q} 3$ & 0.019 & 0.017 & 1.07 \\
$2007 / \mathrm{Q} 4$ & 0.019 & 0.017 & 1.12 \\
$2008 / \mathrm{Q} 1$ & 0.020 & 0.019 & 1.01 \\
$2008 / \mathrm{Q} 2$ & 0.020 & 0.021 & 0.97 \\
$2008 / \mathrm{Q} 3$ & 0.021 & 0.023 & 0.88 \\
$2008 / \mathrm{Q} 4$ & 0.021 & 0.025 & 0.85 \\
$2009 / \mathrm{Q} 1$ & 0.022 & 0.021 & 1.05 \\
$2009 / \mathrm{Q} 2$ & 0.022 & 0.023 & 0.97 \\
$2009 / \mathrm{Q} 3$ & 0.023 & 0.023 & 0.97 \\
$2009 / \mathrm{Q} 4$ & 0.023 & 0.024 & 0.96 \\
$2010 / \mathrm{Q} 1$ & 0.024 & 0.025 & 0.95 \\
$2010 / \mathrm{Q} 2$ & 0.024 & 0.028 & 0.86 \\
$2010 / \mathrm{Q} 3$ & 0.025 & 0.029 & 0.86 \\
$2010 / \mathrm{Q} 4$ & 0.026 & 0.027 & 0.95 \\
\hline
\end{tabular}

Public investment data is seasonally adjusted.

Source: IPEA. 


\section{A.2 Short-Term Impact of Time-to-Build Process}

A.2.1 Basic Model with Alternative Calibration $(\theta=0)$

Figure A1 - Response for public investment shock: Consumption taxation $\left(\tau^{c}\right)$
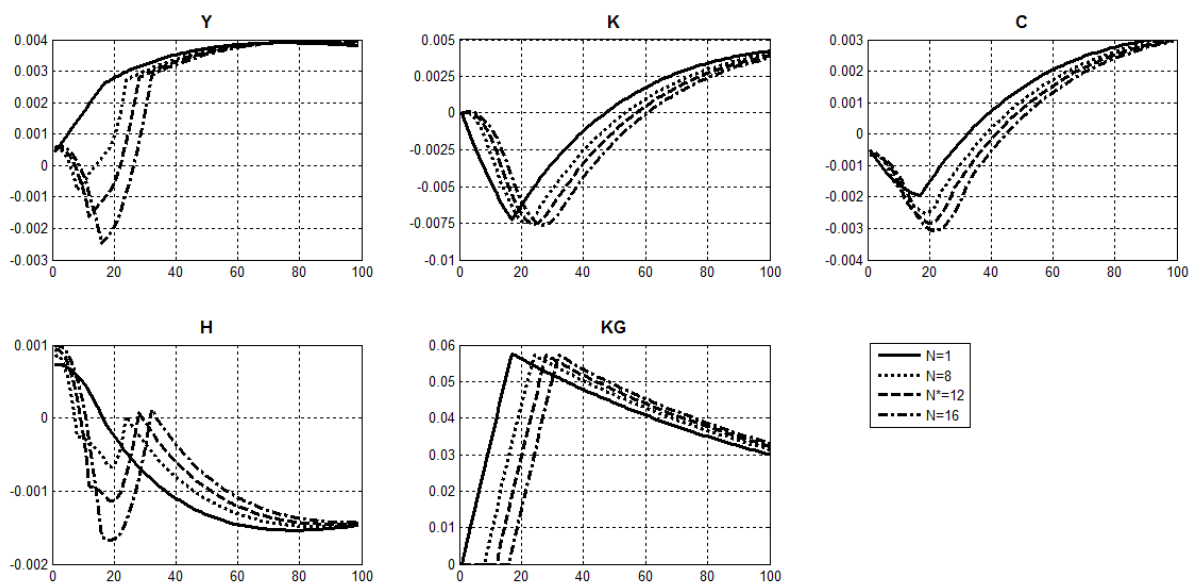

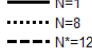

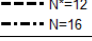


Figure A2 - Response for public investment shock: Labor taxation $\left(\tau^{h}\right)$
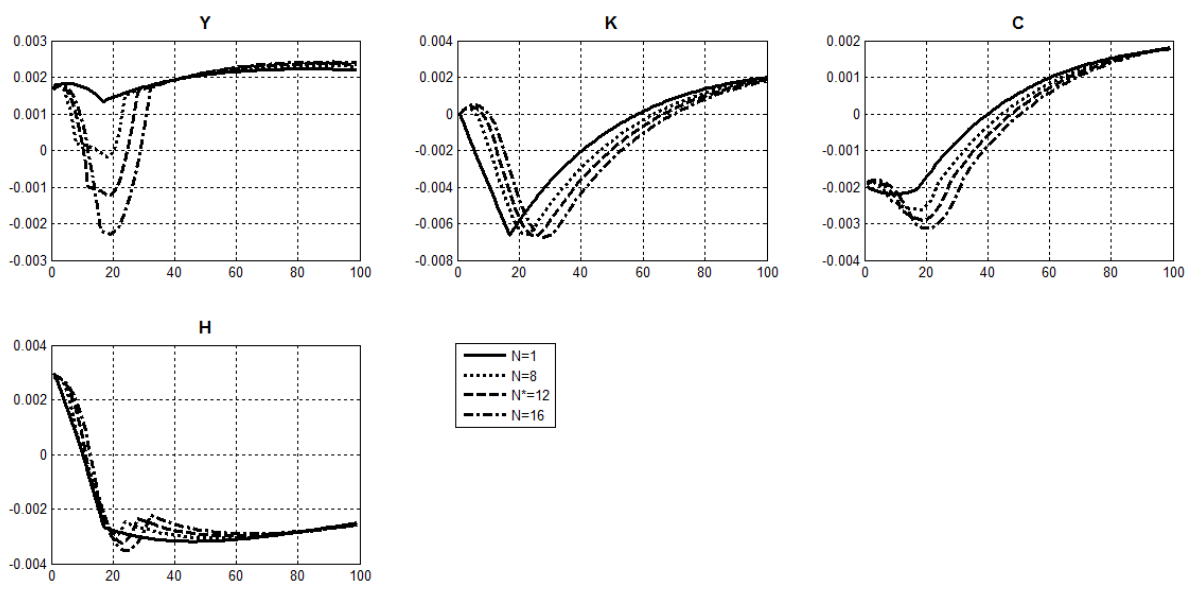

\section{$\mathrm{N}=1$
$\cdots \cdots .$.
$\cdots$ $\because \cdot-\cdot N^{*}=12$}

Figure A3 - Response for public investment shock: Capital taxation $\left(\tau^{k}\right)$
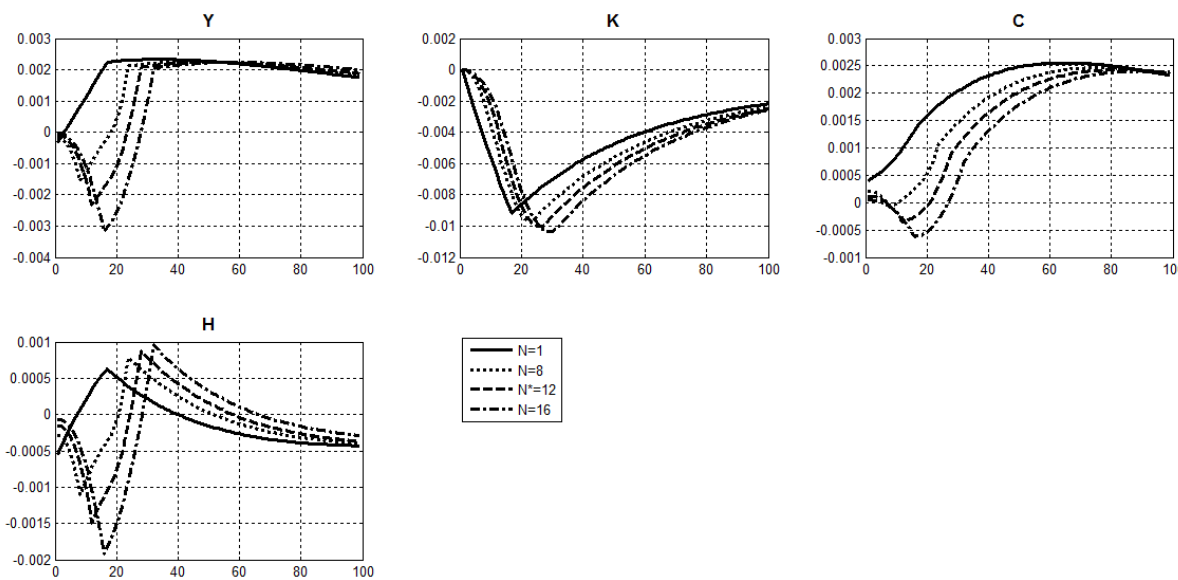

$--\cdot \mathrm{N}^{*}=12$
$-\cdot-\cdot \mathrm{N}=16$ 
A.2.2 Basic Model with Alternative Calibration $(\theta=1)$

Figure A4 - Response for public investment shock: Consumption taxation $\left(\tau^{c}\right)$
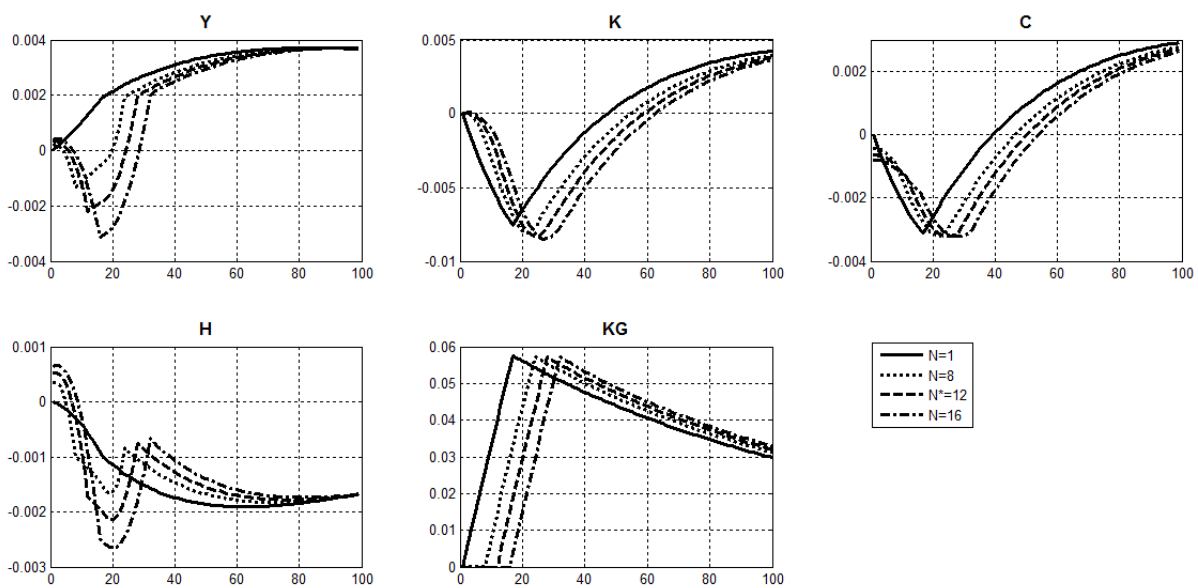

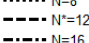


Figure A5 - Response for public investment shock: Labor taxation $\left(\tau^{h}\right)$
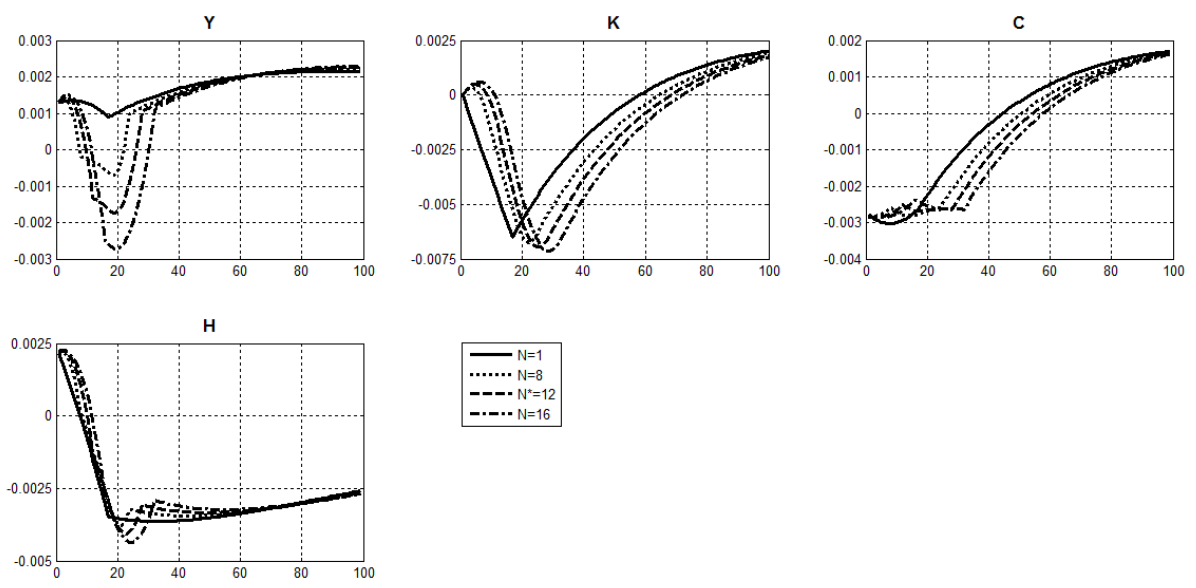

Figure A6 - Response for public investment shock: Capital taxation $\left(\tau^{k}\right)$
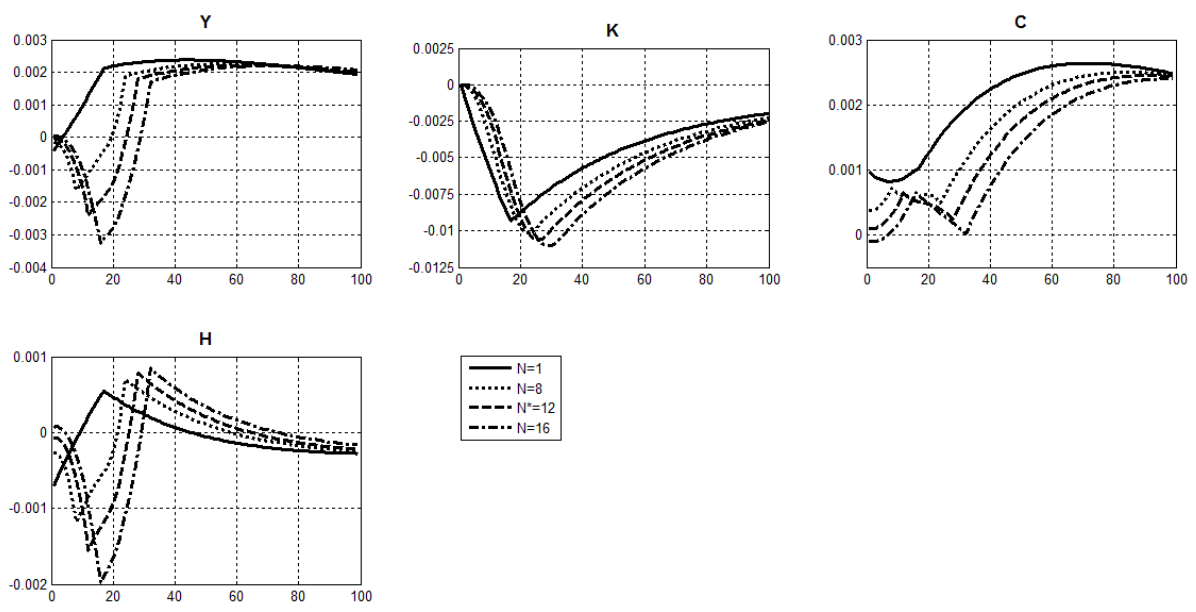
A.3 Impact of Fiscal Adjustment Flexibility

A.3.1 Three-year Time Lag with Alternative Calibration $(\theta=0)$

Figure A7 - Response for public investment shock: Consumption taxation $\left(\tau^{c}\right)$
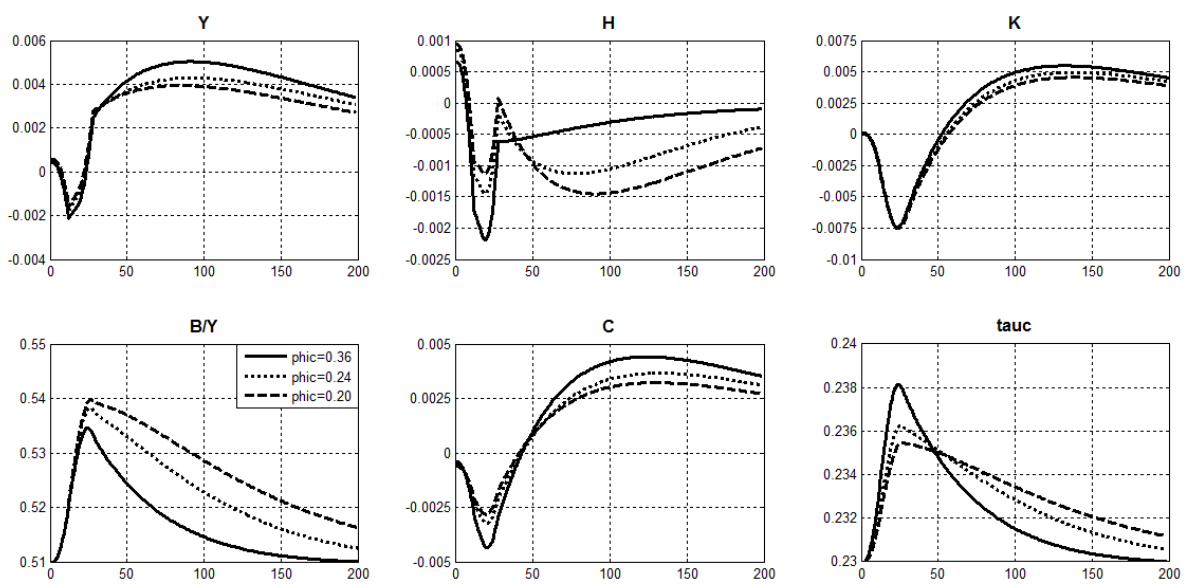
Figure A8 - Response for public investment shock: Labor taxation $\left(\tau^{h}\right)$
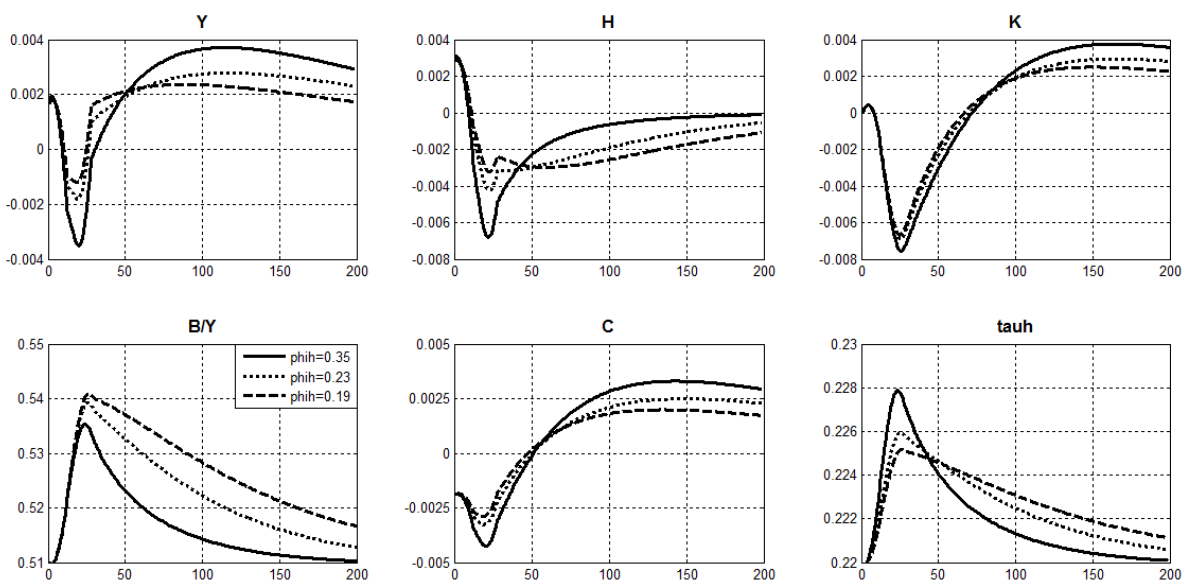

Figure A9 - Response for public investment shock: Capital taxation $\left(\tau^{k}\right)$
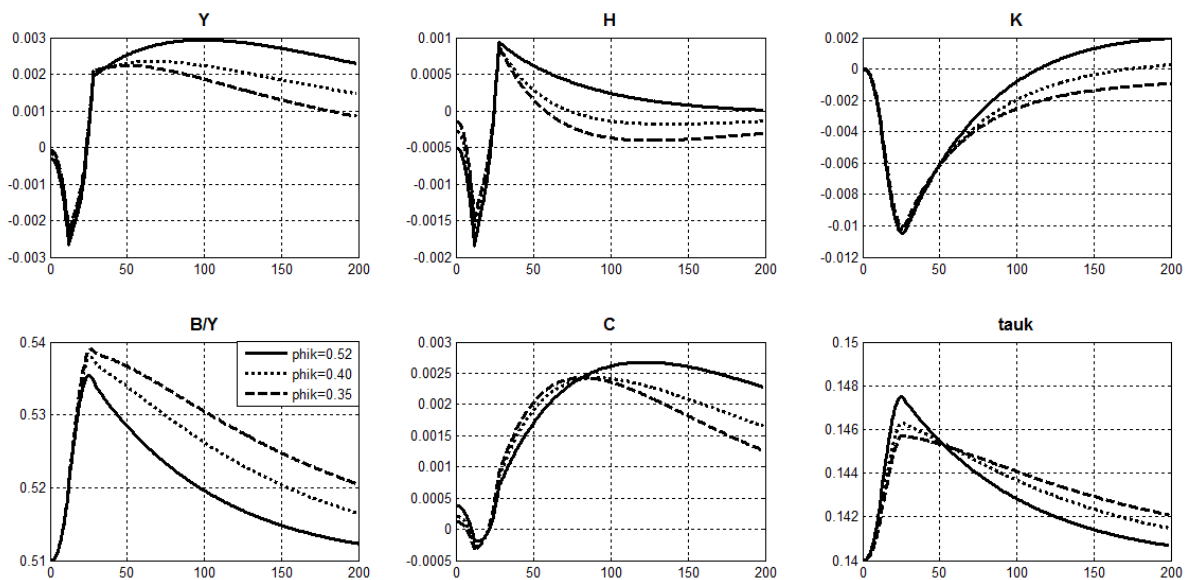
A.3.2 Three-year Time Lag with Alternative Calibration $(\theta=1)$

Figure A10 - Response for public investment shock: Consumption taxation $\left(\tau^{c}\right)$
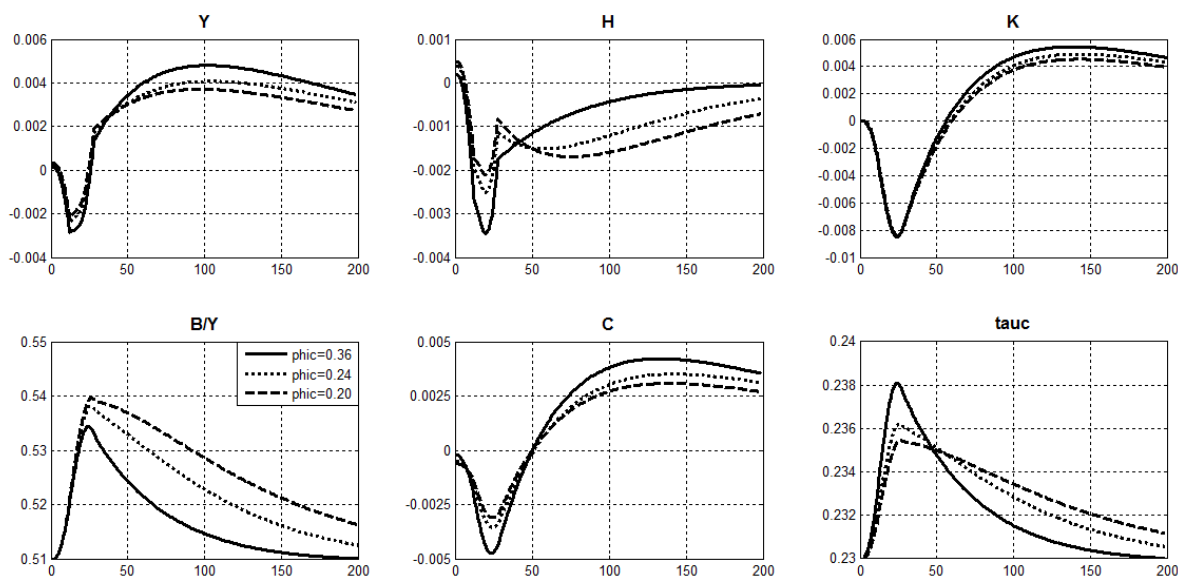
Figure A11 - Response for public investment shock: Labor taxation $\left(\tau^{h}\right)$
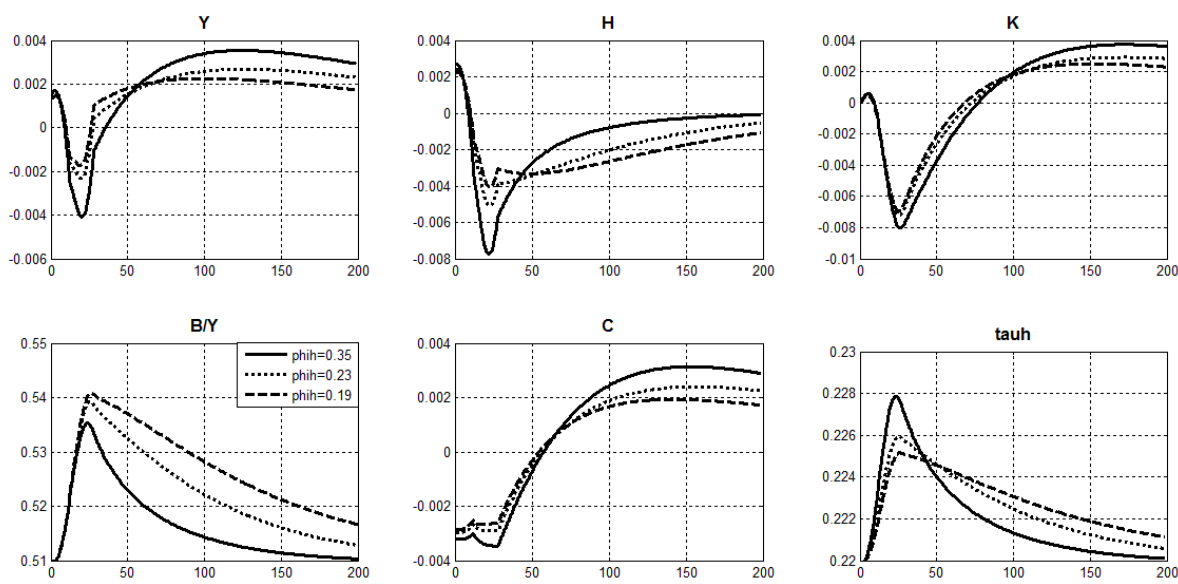

Figure A12 - Response for public investment shock: Capital taxation $\left(\tau^{k}\right)$
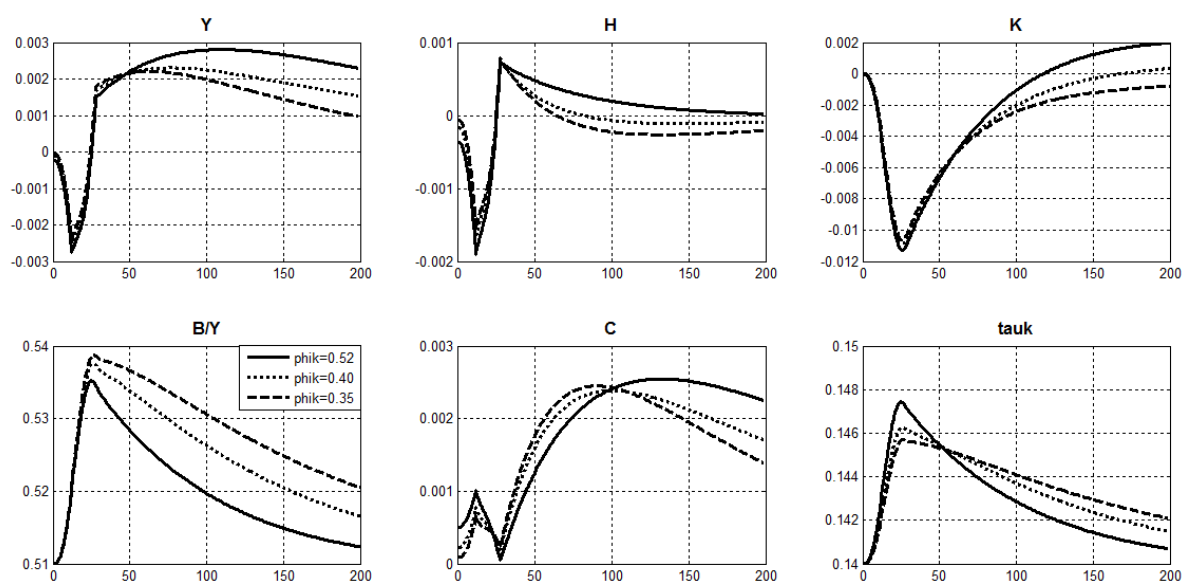